\title{
Wastewater Treatment for Pathogen Removal and Nutrient Conservation: Suitable Systems for Use in Developing Countries
}

\author{
Blanca Jiménez, Duncan Mara, Richard Carr \\ and François Brissaud ${ }^{1}$
}

\begin{abstract}
This chapter summarizes the main characteristics of wastewater treatment processes, especially those suitable for use in developing countries, from the perspective of their potential to produce an effluent suitable for safe agricultural irrigation; it thus concentrates on pathogen removal and nutrient conservation. Wastewater treatment processes are divided into two principal categories: 'natural' systems which do not rely on the consumption of large amounts of electrical energy and which are therefore more suitable for use in developing countries; and conventional electromechanical systems which are wholly energy-dependent and which, if used in low income regions, require high levels of financial investment for their construction and skilled manpower for their successful operation and maintenance. The removal of viral, bacterial, protozoan and helminthic pathogens achieved by the most commonly used natural and conventional treatment processes are detailed, and recommendations are made for process selection.
\end{abstract}




\section{INTRODUCTION}

In order to treat municipal wastewater so that it can be safely used for agricultural purposes it is important to conserve nutrients while at the same time removing pathogens. This imposes constraints for process selection that are very different from those used for organic matter (i.e. biochemical oxygen demand, BOD) removal which is the principal concern of wastewater treatment prior to discharge to surface waters. To achieve effective pathogen removal requires a very careful selection of treatment processes since several pathogen groups - viral, bacterial, protozoan and helminthic - have to be removed to varying degrees and, in developing countries, at the lowest possible cost.

The information presented in this chapter, which is complementary to that in Chapter 9 (faecal sludge treatment), and Chapters 10 and 12 (both on posttreatment options), is a summary of the main characteristics of wastewater treatment processes, especially those suitable for use in developing countries, viewed from the perspective of their potential to produce an effluent suitable for agricultural irrigation, rather than to describe their design and operational principles (which can be found in the specialist literature and some of the references given herein).

\section{WASTEWATER CHARACTERISTICS}

Worldwide, municipal wastewaters have a broadly similar composition with regard to their content of organic matter and nutrients, but not their microbiological characteristics. Due to the difference in health conditions of people living in industrialized and developing countries, the pathogen content is notably different (Jiménez, 2003) and therefore the appropriate treatment options are also different. Table 8.1 shows the pathogen contents in wastewaters from different countries, from which it is apparent that, in order to attain values of $\leq 1$ helminth egg per litre and $\leq 10^{3}-10^{4}$ faecal coliforms per $100 \mathrm{ml}$ in treated wastewater to be used for agricultural irrigation (as recommended in the 2006 WHO Guidelines - see Chapters 2 and 5), the removal efficiencies required are of the order of 95-99.99 per cent for helminth eggs ${ }^{2}$ and 3-6 log units ${ }^{3}$ for faecal coliforms.

Removal of helminth eggs, bacteria and viruses is commonly achieved by wastewater stabilization ponds and other 'natural' treatment processes. However, when more 'conventional' or energy-intensive processes (e.g. activated sludge) are used, disinfection methods such as chlorination, ozonation and UV radiation are generally required for pathogen inactivation. These disinfection methods remove bacteria and viruses, but not helminth eggs as these are very resistant and behave quite differently from bacteria and viruses during treatment. Protozoan (oo)cysts are only slightly less resistant than helminth eggs (details of the removal mechanisms of helminth eggs can be found in Jiménez, 2007, 2009). Thus, special care must be 
Table 8.1 Concentrations of micro-organisms in wastewater and wastewater sludge in different countries

\begin{tabular}{|c|c|c|c|}
\hline Micro-organism & Country/Region & Wastewater & Sludge \\
\hline \multirow{16}{*}{$\begin{array}{l}\text { Helminth eggs } \\
\text { (per litre) }\end{array}$} & Developing countries & 70-3000 & $70-735$ \\
\hline & Brazil & 166-202 & 75 \\
\hline & Egypt & $\mathrm{N} / \mathrm{A}$ & Mean: 67 \\
\hline & Ghana & $0-15$ & $\begin{array}{l}\text { Max: } 735 \\
76\end{array}$ \\
\hline & Jordan & 300 & $\mathrm{~N} / \mathrm{A}$ \\
\hline & Mexico & $6-98$ & $73-177$ \\
\hline & & (up to 330 in poor areas) & \\
\hline & Morocco & $214-840$ & N/A \\
\hline & Pakistan & 142 (Ascaris) & $\mathrm{N} / \mathrm{A}$ \\
\hline & & $\begin{array}{l}558 \text { (Ascaris, Ancylostoma and } \\
\text { Necator) }\end{array}$ & \\
\hline & Ukraine & $20-60$ & $\mathrm{~N} / \mathrm{A}$ \\
\hline & France & $9-10$ & $5-7$ \\
\hline & Germany & $\mathrm{N} / \mathrm{A}$ & $<1$ \\
\hline & Great Britain & $\mathrm{N} / \mathrm{A}$ & $<6$ \\
\hline & Irkutsk, Russia & 19 & $\mathrm{~N} / \mathrm{A}$ \\
\hline & USA & $1-8$ & $2-13$ \\
\hline \multirow{3}{*}{$\begin{array}{l}\text { Faecal coliforms } \\
\text { (per 100ml) }\end{array}$} & Ghana & $10^{4}-10^{9}$ & \\
\hline & Mexico & $10^{7}-10^{9}$ & \\
\hline & USA & $10^{6}-10^{9}$ & \\
\hline \multirow{5}{*}{$\begin{array}{l}\text { Salmonella spp. } \\
\text { (per 100ml) } \\
\text { Protozoan cysts } \\
\text { (per litre) }\end{array}$} & Mexico & $10^{6}-10^{9}$ & \\
\hline & USA & $10^{3}-10^{6}$ & \\
\hline & Mexico & 978-1814 & \\
\hline & & $\begin{array}{l}\text { (Entamoeba histolytica, Giardia } \\
\text { lamblia and Balantidum coli) }\end{array}$ & \\
\hline & USA & 28 (Cryptosporidium) & \\
\hline
\end{tabular}

Source: Jiménez (2005, 2007); Jiménez et al. (2004); N/A not available

taken when selecting a process that removes helminth eggs and protozoan (oo)cysts from wastewater to the required degree.

\section{Classification OF TREATMENT STEPS}

Conventionally there are four treatment steps to be considered: preliminary, primary, secondary and tertiary.

Preliminary treatment comprises screening and grit removal for the extraction of coarse suspended solids, such as fats, oils and greases, sand, gravel, rocks and any large floating materials (e.g. plastics, wood, etc.). Pathogen or nutrient concentration levels are not affected. In developed countries sophisticated proprietary equipment, often with remote operation and control, is employed. Developing countries commonly rely on low-cost equipment like manually raked bar screens and manually cleaned grit channels. 
Primary treatment is commonly primary sedimentation, although septic tanks, Imhoff tanks, upflow anaerobic sludge-blanket (UASB) reactors, and anaerobic ponds, including high-rate anaerobic ponds (HRAP), also serve this purpose. In these processes, which have a hydraulic retention time of a few hours, almost all the settleable solids in the wastewater sediment sink to the base of the reactor, from where they are regularly removed (commonly continuously or at least once a day for primary sedimentation tanks, every few weeks for UASBs, and every one to three years for septic and Imhoff tanks and anaerobic ponds). The sludge so produced contains viable pathogens (notably helminth eggs) and requires further treatment before any application to agricultural land (other than by subsurface soil injection).

Secondary treatment systems follow primary treatment and are most frequently biological processes coupled with solid/liquid separation. Secondary aerobic treatment processes comprise a biological reactor followed by a secondary sedimentation tank to remove and concentrate the biomass produced from the organic compounds in the wastewater. Aerobic reactors use either suspendedgrowth processes (e.g. aerated lagoons, activated sludge, oxidation ditches) or fixed-film processes (trickling filters, rotating biological contactors). Although conventional secondary treatment systems are designed primarily for the removal of BOD, suspended solids and often nutrients (nitrogen and phosphorus), they can, with optimized performance, also reduce bacterial and viral pathogens by approximately 90 per cent, protozoan (oo)cysts by $0-1$ log unit and helminth eggs by around $2 \log$ units, depending on the concentration of suspended solids.

Tertiary treatment refers to treatment processes downstream of secondary treatment such as: additional solids removal by flocculation, coagulation and sedimentation; granular medium filtration; and/or disinfection. When tertiary treatment processes are used, the overall sequence of wastewater treatment processes is often described as 'advanced wastewater treatment'. Tertiary treatment, and in some cases even secondary (depending on the process selected), is typically unaffordable and often too complex to operate satisfactorily in many low-income countries.

Since these wastewater treatment processes can be applied at different treatment steps (primary, secondary, tertiary or even in between), each treatment process will be analysed in this chapter as a single unit and its role at different levels of treatment discussed.

\section{DESCRIPTION OF TREATMENT PROCESSES}

'Natural' wastewater treatment processes include waste stabilization ponds, wastewater storage and treatment reservoirs, septic tanks, Imhoff tanks, UASB reactors, high-rate anaerobic ponds and constructed wetlands, which use a low amount of energy for operation. Energy-intensive systems include aerated lagoons, 
activated sludge systems including oxidation ditches, biofilters and rotating biological contactors - all of these, except oxidation ditches and aerated lagoons, are preceded by primary sedimentation and all are followed by secondary sedimentation and, if required, by disinfection, commonly through chlorination or maturation ponds. Infiltration-percolation can be used for the further treatment of primary and secondary effluents, and soil-aquifer treatment for tertiary-treated effluents.

\section{Waste stabilization ponds}

Waste stabilization ponds (WSP) are shallow basins that use natural factors such as biodegradation, sunlight, temperature, sedimentation, predation and adsorption to treat wastewater (Mara, 2004). WSP systems usually consist of anaerobic, facultative and maturation ponds arranged in series. For optimal performance the ponds should be designed in such a way as to minimize hydraulic short-circuiting and care must be taken during operation to avoid irregular solids accumulation modifying the flow pattern. In tropical environments well-designed and properly operated WSP systems are very efficient at removing all kinds of pathogens without the addition of chemicals: they can reliably achieve a 2-4 log unit removal of viruses, a 3-6 log unit removal of bacterial pathogens, a 1-2 log unit removal of protozoan (oo)cysts and up to a 3 log unit (i.e. very close to 100 per cent) removal of helminth eggs - the precise values depend on the number of ponds in series and their retention times (Grimason et al., 1996; Mara, 2004; Mara and Silva, 1986; Oragui et al., 1987).

Protozoan (oo)cysts and helminth eggs are removed by sedimentation and thus remain in the pond sludge. Viruses are removed by adsorption onto solids, including algae; if these solids settle, the adsorbed viruses also remain in the pond sludge. Bacteria are removed or inactivated by several mechanisms including temperature, $\mathrm{pH}$ values $>9.4$ (induced by rapid algal photosynthesis), and a combination of high light intensity ( $>450 \mathrm{~nm}$ wavelength) and high dissolved oxygen concentrations (Curtis et al., 1992).

To remove helminth eggs, a minimum total retention time in a WSP series of 5-20 days, depending on their number in the raw wastewater, is required (Mara, 2004). To control Cryptosporidium almost 38 days are needed (Grimason et al., 1996; Mara, 2004; Shuval et al., 1986). When a series of ponds are used, most of the helminth eggs are retained in the first pond. Helminth eggs remain viable for several years in the pond sludge: for example, from a survey of several WSP in Mexico, a content of 14 viable eggs per g TS was found in sludge stored for at least nine years (Nelson et al., 2004).

WSP are most effective in warm climates. In colder climates they can still be effective but they require a longer retention time and thus an even greater land area. In hot, arid and semi-arid climates substantial water loss occurs due to evaporation, causing not only a net loss of irrigation water but also an increase in the effluent salinity. Values up to 20-25 per cent of water loss have been reported (Duqqah, 
2002; Jiménez, 2005; Jiménez, 2007). In the centre of Mexico, farmers have refused to use treated wastewater due to its high salinity and in Pakistan farmers have avoided the use of treated wastewater in favour of untreated wastewater for similar reasons (Clemett and Ensink, 2006).

WSP are most commonly the lowest-cost treatment option in tropical environments where inexpensive land is available (Arthur, 1983). They are relatively easy to operate and maintain, and do not require electricity. However, the growth of vegetation in or near the ponds must be controlled to prevent the creation of vector-breeding habitats.

\section{Wastewater storage and treatment reservoirs}

Wastewater storage and treatment reservoirs (WSTR), also called effluent-storage reservoirs, are used in several arid and semi-arid countries. They offer the advantage of storing and treating wastewater until it can be used during the irrigation season, so allowing the whole year's wastewater to be used in the irrigation season and therefore increasing agricultural production by increasing the area of land irrigated. Procedures for designing WSTR are detailed in Juanicó and Dor (1999) and Mara (2004). WSTR are generally used after primary treatment, typically after an anaerobic pond, although they can be used to store and treat secondary effluents (i.e. to upgrade an existing wastewater treatment plant).

WSTR remove 2 to $4 \log$ units of viruses, 3 to $6 \log$ units of bacterial pathogens and 1 to $2 \log$ units of protozoan (oo)cysts. If treatment reservoirs are operated as batch systems with retention times over 20 days the complete removal of helminth eggs can be achieved (Jiménez, 2007; Juanicó and Milstein, 2004). WSTR have much lower evaporative losses compared to those from WSP: 14 per cent vs. 25 per cent (Mara et al., 1997).

In addition to large WSTR, small intermediate storage ponds can be utilized for pathogen removal prior to wastewater use in urban agriculture. Such reservoirs reduce helminth egg numbers by around 70 per cent, provided care is taken not to disturb the sediments when removing the WSTR contents for use (Drechsel et al., 2008). They are easy to operate and maintain, and if considered as part of the irrigation system, they result in a low investment cost. However, they may facilitate vector breeding if they are not well maintained and operated, and algal development may clog the irrigation distribution system (such as sprinklers and emitters).

\section{Septic tanks, Imhoff tanks, UASBs and high-rate anaerobic ponds}

These are all natural treatment systems roughly equivalent to primary treatment but with the potential to capture the anaerobically produced biogas which, as 
it comprises over 60 per cent methane, can be used for cooking and lighting at household level or, at larger treatment works, for electricity generation.

Septic tanks, which date from the late 19th century, are simple wastewater solid/liquid separation tanks often used at household level with on-site drainfields or soakaways to dispose of the settled effluent from the tank, although they can also be used at small wastewater treatment works with the settled effluent being treated further in WSP or a constructed wetland. Imhoff tanks, which were developed in Germany in 1906, are a modification of septic tanks for small treatment works: the tank has an improved design to facilitate better solid/liquid separation.

A more recent development, dating from the 1980s, is the UASB reactor. These are normally only used at wastewater treatment plants (either small or large - the largest in the world, in Belo Horizonte, Brazil, has a design population of 1 million). In a UASB the wastewater enters the reactor at its base and is treated during its passage through a sludge bed (the sludge 'blanket') formed by tight floccules of anaerobic bacteria. The hydraulic retention time is 6-12 hours (Mara, 2004). The treatment process is designed primarily for the removal of organic matter, but UASBs remove 86-98 per cent of helminth eggs, and effluent egg numbers are highly variable. In Brazil for example, UASB effluents contain three to ten eggs per litre, but with high numbers in the raw wastewater (up to 320 eggs per litre) effluent numbers can be as high as 45 per litre (Sperling et al., 2002, 2003, 2004). To remove helminth eggs from UASB effluents completely and reliably, it is recommended to treat the effluent further in WSP which also reduce faecal coliform levels to those recommended in the 2006 WHO Guidelines. Investigations of effluent nitrogen and phosphorus levels in UASB effluents do not indicate significant losses (Ali et al., 2007; van Lier et al., 2002); however, losses may occur due to increased $\mathrm{pH}$ in polishing ponds treating UASB effluents (Cavalcanti, 2003).

UASBs are often considered a low-cost technology; however, they are more expensive but not more efficient than conventional anaerobic ponds (Peña et al., 2000). A lower-cost but equally efficient alternative to UASBs is the high-rate anaerobic pond which combines the simplicity of conventional anaerobic ponds and the higher performance of UASBs, including the option of biogas recovery, at a much lower cost than the latter (Peña Varón, 2002).

\section{Constructed wetlands}

Constructed wetlands are beds of aquatic macrophytes which grow in soil, sand or gravel. There are three main types: surface-flow, subsurface horizontal-flow and vertical-flow systems. Although, in principle, any aquatic macrophyte can be grown in constructed wetlands, and high-value ornamental flowers and trees have been grown successfully in constructed wetlands, the majority are planted with reeds and/or rushes (e.g. Juncus, Phragmites) (Belmont et al., 2004). 
Constructed wetlands are usually secondary or tertiary treatment units, in which case they are preceded by a septic tank, Imhoff tank, UASB, anaerobic pond or a conventional wastewater treatment plant. They are used to remove organic matter (BOD), solids and nutrients. Wetlands are generally promoted as a good option to control pathogens. However, although wetlands have been installed in several developing countries, in practice few data on the pathogen removals obtained are available due to the high cost and complexity of the analytical techniques involved. The available information mostly refers only to faecal coliforms. From the small amount of available data, pathogen removal is highly variable and depends on the climate, the type of wetland and the plants used. Pathogen removal is achieved via filtration, adsorption on to soil or plant roots and predation by micro-organisms (Jiménez, 2007). Wetlands can remove 90-98 per cent of faecal coliforms, 67-84 per cent of MS2 coliphages and 60-100 per cent of protozoa (Jiménez, 2003). Further details are given in Rivera et al. (1995) and IWA Specialist Group (2000).

Constructed wetlands can be sources of nuisance mosquitoes, some of which have public-health implications (e.g. Culex quinquefasciatus, the vector in many parts of the developing world of Bancroftian filariasis). Reports from the eastern USA, southern Sweden and Australia detail this phenomenon and present possible environmental management solutions (Russell, 1999; Schäfer et al., 2004). Clearly, locating constructed wetlands (especially surface-flow wetlands) at safe distances from human settlements is important.

\section{Primary sedimentation}

Primary treatment is achieved in tanks having a retention time of two to six hours. Removal occurs through sedimentation, therefore small pathogens such as bacteria and viruses are only removed if they are adsorbed on to or are trapped within a matrix of settleable solids. For helminth eggs, removal efficiencies of less than 30 per cent can be expected.

\section{Coagulation-flocculation}

Coagulation-flocculation has been sometimes used as the main treatment process to produce a treated wastewater suitable for agricultural use at a reasonable cost. This requires low coagulant doses combined with high-molecular-weight and high-density-charge flocculants to reduce sludge production (Jiménez, 2009). Two coagulation-flocculation technologies fulfil this requirement: chemically enhanced primary treatment (CEPT) and advanced primary treatment (APT). These differ in that CEPT uses a conventional settler and APT uses a high-rate lamellar settler. Hydraulic retention time is four to six hours for the former but only half to one hour for the latter. They are both efficient at removing helminth eggs 
while allowing part of the organic matter and nutrient (nitrogen and phosphorus) content to remain in the dissolved and colloidal fractions of the treated water. However, in both cases the effluent produced still needs a disinfection step to inactivate bacteria and viruses; this can be achieved with chlorine or UV light (Jiménez, 2007). Helminth eggs and some protozoa are removed along with the suspended solids following the same coagulation-flocculation removal principles. The low total suspended solids (TSS) content achieved during the process has the additional advantage of allowing the use of the treated effluent for sprinkler or drip irrigation.

Different coagulants can be used, with ferric and alum coagulants being the most common (Jiménez, 2003). Lime has been used at very high doses (more than $1000 \mathrm{mg} /$ litre) to coagulate but also to raise the $\mathrm{pH}$ to inactivate $4.5 \mathrm{log}$ of faecal coliforms using a contact time of 9-12 hours. Unfortunately, sludge production is high and lime easily forms deposits creating clogging problems (Gambrill, 1990; Jiménez and Chávez, 2002; Jiménez and Chávez Mejia, 1997). The cost of the APT is only one-third of the cost of a conventional activated sludge system, including sludge treatment and disposal (within $20 \mathrm{~km}$ ) (Jiménez and Chávez, 2002). APT removes $1 \log$ of faecal coliforms, $1 \log$ Salmonella spp., 50-80 per cent of protozoa cysts (Giardia, Entamoeba coli and E. histolytica) and 90-99 per cent of helminth ova (Jiménez et al., 2001). From a content of up to 120 eggs/litre, APT may consistently produce an effluent with $0.5-3$ eggs/litre (Chávez et al., 2004; Jiménez et al., 2001). With regard to nutrients, the total nitrogen removal is of the order 13 per cent with ferric chloride, 17 per cent with alum and 12 per cent with lime; the main fraction removed is organic nitrogen. Phosphorus removal was 20 per cent for ferric chloride, 15 per cent for alum and 54 per cent for lime.

Coagulation-flocculation can also be used as a tertiary treatment process. Chemicals (e.g. ferric chloride, ferrous chloride, aluminium sulphate, calcium oxide) are added to secondary effluents which cause very small particles to combine or aggregate; these larger aggregated particles then settle out of the liquid. Increasing particulate matter removal also increases viral and bacterial removals as they are often solids-associated - for example, viruses can be reduced by $2-3 \log$ units under optimal conditions (Jiménez, 2003).

\section{Secondary biological treatment}

There are several options to treat wastewater biologically at a secondary level, all of them aerobic. These processes efficiently remove organic matter and, to a lesser extent, nutrients. They are high cost and complex to operate. The most widely used process is activated sludge, but other secondary treatments include aerated lagoons, oxidation ditches and trickling filters. There is an extensive specialized literature describing these processes and detailing their design (e.g. Metcalf and Eddy, Inc., 2003). 
It is worth noting that Arthur (1983), in an economic comparison of WSP, aerated lagoons, oxidation ditches and trickling filters for the city of Sana'a, found that WSP were the least cost option up to land prices of US\$50,000-150,000 (depending on the discount rate used), above which oxidation ditches were the cheapest treatment option, with aerated lagoons and trickling filters always being much more expensive. (The costing methodology used by Arthur was very rigorous and it still recommended for use today.)

\section{Membrane bioreactors}

Effluents from activated sludge aeration tanks may be further treated by passage through membranes. These membranes have a very small pore size $(20-500 \mathrm{~nm})$, so they operate in the ultrafiltration and microfiltration ranges. They are thus able to achieve essentially complete reduction (i.e. $>6$ log units) of all pathogens, including viruses. However, membranes are very complex and expensive to operate, and membrane fouling is a particular concern, although costs and the complexity of operation are decreasing as the technology improves (Stephenson et al., 2000). Membrane bioreactors provide an extremely efficient, but correspondingly very expensive, combination of secondary and tertiary treatment. Often the effluent quality is far in excess of what is required (and thus may be considered to be a suboptimal use of scarce resources).

\section{Filtration}

Filtration is a useful treatment step to remove protozoan (oo)cysts and helminth eggs from effluents resulting from a primary or a secondary treatment step, whether this is physicochemical (Landa et al., 1997) or biological, such as activated sludge (Jiménez, 2007). During filtration, pathogens and other particulate matter are removed as they pass through sand or other porous granular media. Pollutants are retained by sieving, adsorption, straining, interception and sedimentation. There are several types of filtration including high-rate granular filtration $\left(>2 \mathrm{~m}^{3} / \mathrm{m}^{2} \mathrm{~h}\right)$, slow sand filtration, and single and multiple media filtration. Efficient slow sand filtration requires optimal maturation of the surface microbiological layer (the 'schmutzdecke'), cleaning and refilling without short-circuiting (WHO, 2004).

Rapid sand filtration removes approximately $1 \mathrm{log}$ unit of faecal coliforms, pathogenic bacteria (Salmonella and Pseudomonas aeruginosa) and enteroviruses, 50-80 per cent of protozoan cysts (Giardia, Entamoeba coli and E. histolytica) and 90-99 per cent of helminth ova (Jiménez et al., 2001) from coagulated primary effluent (these efficiencies can be improved if coagulants are added at the filter entrance). The specific size of the sand medium is $0.8-1.2 \mathrm{~mm}$, the minimum filter depth is $1 \mathrm{~m}$, filtration rates are $7-10 \mathrm{~m}^{3} / \mathrm{m}^{2} \mathrm{~h}$ and the filtration cycles are 20-35 hours. Under these conditions, the effluent consistently contains $<0.1$ helminth 
egg per litre (Jiménez, 2007; Landa et al., 1997). In dual media filtration, used as a tertiary treatment and combined with a coagulation process, bacterial reduction can increase from approximately $1 \log$ unit to 2-3 log units (WHO, 2004).

\section{Conventional disinfection}

The effectiveness of disinfection depends upon several factors, including the type of disinfectant, its contact time with the wastewater, temperature, $\mathrm{pH}$, effluent quality and type of pathogen (WEF, 1996). Chlorine (free chlorine), ozone and ultraviolet radiation are the principal disinfectants used to treat wastewater, although chloramines may be used for advanced primary treatment effluents. Disinfection should be optimized for each type of disinfectant. In general, bacteria are highly susceptible to all three disinfectants; helminth eggs and protozoan (oo)cysts are most resistant to chlorine and ozone; and certain viruses (e.g. adenoviruses) are most resistant to UV disinfection. Chlorine inactivates $1-3 \mathrm{log}$ units of viruses, $2 \log$ units of bacteria, 0-1.5 log units of protozoan (oo)cysts, but almost no helminth eggs. Similar results are found with the other disinfectants, but ozonation is much more efficient at inactivating viruses and UV radiation results in better inactivation of protozoa.

\section{Infiltration-percolation}

Infiltration-percolation consists essentially of intermittently infiltrating wastewater through 1.5 to $2.0 \mathrm{~m}$ deep unsaturated coarse sand beds. These systems treat primary or secondary effluents. As the mean hydraulic load of primary and secondary effluents cannot exceed, respectively, about 0.25 and $0.65 \mathrm{~m}^{3}$ per day per $\mathrm{m}^{2}$ of sand-bed area, the use of infiltration-percolation systems is restricted to small works serving only a few thousand people, although they can be used to serve populations up to approximately 25,000 when treating secondary effluents. Larger plants would require too much filter surface and sand volume.

This low-energy consumption technology is proven to be an efficient means of reclaiming primary or secondary effluents prior to reuse. Full-scale plant monitoring has shown that $E$. coli numbers are reliably reduced to $<1000$ per $100 \mathrm{ml}$ (Salgot et al., 1996). Helminth eggs are completely removed, as are protozoa such as Giardia and Cryptosporidium (Alcalde et al., 2006).

\section{Soil-aquifer treatment}

Pumping tertiary-treated wastewater into a local aquifer (but not one used as a source of drinking water) is one way of storing the wastewater until it is required for irrigation. However, this is an expensive option and it has only been occasionally used - for example, the Dan Region scheme in Israel, which is a very large-scale 
soil-aquifer treatment (SAT) scheme $\left(120-140 \mathrm{Mm}^{3} / \mathrm{yr}\right)$ that has now been operational for more than 30 years (Icekson-Tal et al., 2003). SAT is particularly suitable for unrestricted irrigation as it provides storage as well as treatment to a level comparable to drinking-water quality. However, operation and maintenance are not simple: for example, particular attention has to be paid to optimizing the operation of the recovery wells to prevent high sand concentrations in the pipes and to minimize biofilm growth and iron and manganese deposits (Bixio et al., 2005).

\section{COMPARISON OF TREATMENT METHODS}

Table 8.2 summarizes the main characteristics of the wastewater treatment processes presented here, as well as some others not described in detail. The selection of a specific treatment process needs to be based on local climatic conditions and economic and human resource capabilities.

\section{Conclusions}

For agricultural irrigation in developing countries, it is important to select wastewater treatment processes that both reduce pathogen numbers and retain the nutrients. These are demands that are often difficult to reconcile and therefore a detailed analysis for each particular situation is required. As illustrated by WHO (2006), it is important to reduce pathogen levels before wastewaters are used for crop irrigation. For this to be achieved in practice, only locally viable treatment methods should be selected. Where, for example, institutional capacities to build and maintain treatment plants are limited, as is common in many developing countries, 'low-tech' natural systems should be used, commonly in conjunction with post-treatment health-protection control measures (see Chapter 5). In highincome countries, wastewater treatment coverage becomes more comprehensive and more advanced processes become financially and operationally feasible, so allowing society to rely on wastewater treatment more and more to prevent food contamination from wastewater irrigation.

In addition, knowledge of the types of pathogens and their expected numbers in local wastewaters is required in order to ensure that the selected process is capable of efficiently inactivating or removing them. It is also important to consider the amount and quality of sludge produced during wastewater treatment and how it will be disposed of or locally reused. 
Table 8.2 Characteristics of wastewater treatment processes with reference to their applicability to treatment prior to agricultural reuse in developing countries

\begin{tabular}{lllll}
\hline $\begin{array}{l}\text { Process and } \\
\text { operating } \\
\text { conditions }\end{array}$ & Efficiency & $\begin{array}{l}\text { Nutrient } \\
\text { content }\end{array}$ & Advantages & Disadvantages \\
\hline
\end{tabular}

\section{Natural treatment processes}

$\begin{array}{ll}\text { Waste } & \text { Organic } \\ \text { stabilization } & \text { matter: high } \\ \text { ponds } & \text { Viruses, } \\ \text { (5-20 days' } & \text { bacteria and } \\ \text { retention time) } & \text { protozoa: } \\ & \text { high } \\ & \text { Helminth } \\ & \text { eggs: } \\ & 70-99 \% \text { with } \\ & \text { high reliability }\end{array}$

Wastewater storage and treatment reservoirs

UASB reactors
and HRAP
(6-12 hours'
retention time)

Low to

Low investment and operating costs.

Simple to operate. Requires no electricity. Low sludge production. Appropriate for warm climates with medium to low evaporation rates.

Permits the whole year's wastewater to be used in the irrigation season, so enabling a greater area to be irrigated and thus more crops produced. Does not require a conventional disinfection step

Very low investment and operating costs. Requires no electricity.
Water loss due to evaporation can be high, so leads to increased effluent salinity. High land demand. Algal content in the effluent may clog sprinklers if used. Can facilitate vector breeding if not properly maintained.

Sludge may contain viable pathogens and needs to be carefully managed
Organic

matter: low

Viruses,

bacteria and

protozoa:

high

Helminth

eggs:

70-99\% with

high reliability

$\begin{array}{lll}\text { Organic } & \text { Medium } & \text { Low cost. } \\ \text { matter: very } & \text { to high } & \text { Low sludge } \\ \text { high } & & \begin{array}{l}\text { production. } \\ \text { Requires no }\end{array} \\ \text { Helminth } & & \text { electricity. } \\ \text { eggs: } & & \end{array}$

Effluent can cause odour problems.

Effluent requires further (i.e. secondary) treatment. Sludge needs further treatment. 
Table 8.2 (Continued)

\begin{tabular}{|c|c|c|c|}
\hline $\begin{array}{l}\text { Process and } \\
\text { operating } \\
\text { conditions }\end{array}$ & Efficiency & $\begin{array}{l}\text { Nutrient } \\
\text { content }\end{array}$ & Advantages \\
\hline
\end{tabular}

conditions

\begin{tabular}{llll}
\hline Constructed & Organic & Low to & Low cost. \\
wetlands & matter: high & medium & Easy to operate. \\
(4 days' retention & Pathogens: & & Requires no \\
time in surface- & high for all, & electricity. \\
flow wetlands) & but with low & May improve the \\
& reliability & environment for \\
& Helminth & other species \\
& eggs: & (e.g. birds, \\
& $60-100 \%$ & rodents).
\end{tabular}

High land demand.

Pathogen removal

variable depending upon

a variety of factors.

Needs further treatment

(e.g. filtration) to reliably

remove helminth eggs.

May facilitate mosquito

breeding.

Wildlife excreta may

cause deterioration of

effluent quality.

\section{Primary sedimentation}

\begin{tabular}{|c|c|c|}
\hline $\begin{array}{l}\text { Primary } \\
\text { sedimentation } \\
\text { (2-6 hours' } \\
\text { retention time) }\end{array}$ & $\begin{array}{l}\text { Organic } \\
\text { matter: low } \\
\text { Helminth } \\
\text { eggs: } 30 \% \\
\text { with low } \\
\text { reliability }\end{array}$ & High \\
\hline $\begin{array}{l}\text { CEPT } \\
\text { (low coagulant } \\
\text { doses; 3-4 } \\
\text { hours' retention } \\
\text { time) } \\
\text { Advanced } \\
\text { primary treatment } \\
\text { (low coagulant } \\
\text { doses when } \\
\text { flocculants are } \\
\text { used, } \\
\text { high-rate settlers, } \\
\text { 0.5-1 hour } \\
\text { overall retention } \\
\text { time) }\end{array}$ & $\begin{array}{l}\text { Organic } \\
\text { matter: } \\
\text { medium } \\
\text { Helminth } \\
\text { eggs: high } \\
\text { with high } \\
\text { reliability }\end{array}$ & Medium \\
\hline
\end{tabular}

$\begin{array}{ll}\text { Low cost. } & \text { Low bacterial and viral } \\ \text { Simple } & \text { removals. } \\ \text { technology. } & \text { Effluent needs further } \\ & \text { treatment. } \\ & \text { Sludge needs further } \\ & \text { treatment. }\end{array}$

Low to medium Conventional disinfection cost compared to is required to inactivate activated sludge bacteria.

(third of the cost). Produces more

High efficiency sludge than primary

and reliability. sedimentation,

Low area stabilization ponds and

requirement, wetlands.

notably for the Sludge needs to be

APT. disinfected.

Need to use chemicals.

\section{Secondary treatment processes}

$\begin{array}{lll}\text { Aerated lagoon } & \text { Organic } & \text { Low to } \\ \text { plus settling } & \text { matter: high } & \text { medium } \\ \text { pond } & & \end{array}$

Technology widely Requires electricity. available and well Requires larger land understood.

No need

for primary

sedimentation.

area than other high-rate

processes.

Less expensive

and complex than

Sludge needs

disinfection.

other high-rate

Needs a conventional

disinfection step to

processes. inactivate viruses and bacteria. 
Table 8.2 (Continued)

\begin{tabular}{|c|c|c|c|c|}
\hline $\begin{array}{l}\text { Process and } \\
\text { operating } \\
\text { conditions }\end{array}$ & Efficiency & $\begin{array}{l}\text { Nutrient } \\
\text { content }\end{array}$ & Advantages & Disadvantages \\
\hline Oxidation ditches & $\begin{array}{l}\text { Organic } \\
\text { matter: high }\end{array}$ & $\begin{array}{l}\text { Low to } \\
\text { medium }\end{array}$ & $\begin{array}{l}\text { Technology widely } \\
\text { available and well } \\
\text { understood. } \\
\text { No need } \\
\text { for primary } \\
\text { sedimentation. }\end{array}$ & $\begin{array}{l}\text { Requires electricity. } \\
\text { Sludge needs disinfection } \\
\text { Needs a conventional } \\
\text { disinfection step to } \\
\text { inactivate viruses and } \\
\text { bacteria. }\end{array}$ \\
\hline $\begin{array}{l}\text { Trickling filters } \\
\text { plus secondary } \\
\text { settlers }\end{array}$ & $\begin{array}{l}\text { Organic } \\
\text { matter: high } \\
\text { Helminth } \\
\text { eggs: } \\
\text { medium } \\
\text { removal with } \\
\text { medium } \\
\text { reliability }\end{array}$ & $\begin{array}{l}\text { Low to } \\
\text { medium }\end{array}$ & $\begin{array}{l}\text { Medium operating } \\
\text { costs. } \\
\text { High reliability. } \\
\text { Technology widely } \\
\text { available and well } \\
\text { understood. }\end{array}$ & $\begin{array}{l}\text { High investment costs. } \\
\text { Needs trained staff. } \\
\text { Sludge needs } \\
\text { disinfection. } \\
\text { Needs a conventional } \\
\text { disinfection step to } \\
\text { inactivate viruses and } \\
\text { bacteria. } \\
\text { Fly control required. }\end{array}$ \\
\hline $\begin{array}{l}\text { Activated sludge } \\
\text { plus secondary } \\
\text { sedimentation } \\
\text { (4-8 hours' } \\
\text { retention time in } \\
\text { the reactor) }\end{array}$ & $\begin{array}{l}\text { Organic } \\
\text { matter: high } \\
\text { Helminth } \\
\text { eggs: } \\
\text { 70-90\% with } \\
\text { low reliability }\end{array}$ & $\begin{array}{l}\text { Low to } \\
\text { medium }\end{array}$ & $\begin{array}{l}\text { Removes organic } \\
\text { matter with high } \\
\text { reliability. } \\
\text { Technology widely } \\
\text { available and well } \\
\text { understood. } \\
\text { Easy to control. }\end{array}$ & $\begin{array}{l}\text { High investment and } \\
\text { operating costs. } \\
\text { High energy demand. } \\
\text { Needs trained staff. } \\
\text { Sludge needs } \\
\text { disinfection. } \\
\text { Sludge bulking reduces } \\
\text { helminth egg removal. } \\
\text { Needs a conventional } \\
\text { disinfection step to } \\
\text { inactivate viruses and } \\
\text { bacteria. }\end{array}$ \\
\hline $\begin{array}{l}\text { Membrane } \\
\text { bioreactors }\end{array}$ & $\begin{array}{l}\text { Organic } \\
\text { matter, } \\
\text { suspended } \\
\text { solids and } \\
\text { pathogens: } \\
\text { high }\end{array}$ & Low & $\begin{array}{l}\text { Removes all } \\
\text { pathogens. } \\
\text { Technology } \\
\text { still under } \\
\text { development. }\end{array}$ & $\begin{array}{l}\text { High cost and complexity. } \\
\text { Sludge needs } \\
\text { disinfection. } \\
\text { Membrane fouling. } \\
\text { Needs trained staff. }\end{array}$ \\
\hline \multicolumn{5}{|c|}{ Tertiary treatment processes } \\
\hline $\begin{array}{l}\text { Slow sand } \\
\text { filtration }\end{array}$ & $\begin{array}{l}\text { Organic } \\
\text { matter: } \\
\text { medium } \\
\text { Pathogens: } \\
\text { low to high }\end{array}$ & $\begin{array}{l}\text { Medium } \\
\text { to high }\end{array}$ & $\begin{array}{l}\text { Technology well } \\
\text { known. }\end{array}$ & $\begin{array}{l}\text { More information is } \\
\text { needed on pathogen } \\
\text { removal. } \\
\text { Requires large amount of } \\
\text { space. } \\
\text { Handling of filters during } \\
\text { washing and sludge } \\
\text { removal may create } \\
\text { health concerns. }\end{array}$ \\
\hline
\end{tabular}


Table 8.2 (Continued)

\begin{tabular}{|c|c|c|c|c|}
\hline $\begin{array}{l}\text { Process and } \\
\text { operating } \\
\text { conditions }\end{array}$ & Efficiency & $\begin{array}{l}\text { Nutrient } \\
\text { content }\end{array}$ & Advantages & Disadvantages \\
\hline $\begin{array}{l}\text { Rapid sand } \\
\text { filtration } \\
\left(2 \mathrm{~m}^{3} / \mathrm{m}^{2} \mathrm{~h} \text { with }\right. \\
0.8-1.2 \mathrm{~mm} \text { sand } \\
\text { and } 1 \mathrm{~m} \text { height) } \\
\text { Cycle duration } \\
\text { up to } 35 \mathrm{~h} \text {, for a } \\
\text { primary treatment }\end{array}$ & $\begin{array}{l}\text { Helminth } \\
\text { eggs: high } \\
\text { (90-99\%) } \\
\text { (very high if } \\
\text { coagulant is } \\
\text { added) }\end{array}$ & $\begin{array}{l}\text { High if } \\
\text { used for } \\
\text { primary } \\
\text { effluent }\end{array}$ & $\begin{array}{l}\text { High efficiency. } \\
\text { High reliability. } \\
\text { Improves } \\
\text { pathogen } \\
\text { removal. } \\
\text { Well understood } \\
\text { technology. } \\
\text { Low additional } \\
\text { cost. }\end{array}$ & $\begin{array}{l}\text { Complementary process } \\
\text { to biological or chemical } \\
\text { wastewater treatment. } \\
\text { Implies an additional cost. }\end{array}$ \\
\hline $\begin{array}{l}\text { Coagulation- } \\
\text { flocculation as a } \\
\text { tertiary treatment }\end{array}$ & $\begin{array}{l}\text { Organic } \\
\text { matter: high } \\
\text { Nutrient: } \\
\text { high }\end{array}$ & Low & $\begin{array}{l}\text { Improves removal } \\
\text { of viruses and } \\
\text { other pathogens. } \\
\text { Low additional } \\
\text { cost. }\end{array}$ & $\begin{array}{l}\text { High total cost (primary } \\
+ \text { secondary + tertiary } \\
\text { treatment). } \\
\text { Increases sludge } \\
\text { production. } \\
\text { Sludge needs to be } \\
\text { disinfected. }\end{array}$ \\
\hline
\end{tabular}

\section{Disinfection}

Chlorination: doses and contact time depend on the characteristic of the effluent to be treated

\section{Ozonation: doses and contact time depend on the characteristics of the effluent to be treated}

Bacteria, -
viruses
and some
protozoa:
high

Bacteria
and some
protozoa:
high
Viruses: very
high

UV radiation: doses and contact time depend on the characteristics of the effluent to be treated Bacteria, protozoa: high

\author{
Medium cost \\ but it is the \\ lowest cost for \\ a conventional \\ disinfection \\ method. \\ Well understood \\ technology. \\ High efficiency of \\ virus inactivation. \\ Needs to be applied to \\ effluents with low organic \\ matter and suspended \\ solids contents. \\ Higher cost and complexity \\ than chlorination. \\ Low efficiency of helminth \\ inactivation at economical \\ doses. \\ Needs to be generated on \\ site. \\ Production of hazardous \\ by-products. \\ Needs to be applied to \\ effluents with low organic \\ solids contents. \\ Creates disinfection by- \\ products. \\ Hazardous chemical.
}

$\begin{array}{ll}\text { Similar or higher } & \text { Needs to be applied to } \\ \text { than cost of } & \text { effluents with low organic } \\ \text { chlorination. } & \text { matter and suspended } \\ \text { Effective in } & \text { solids content and high } \\ \text { inactivating } & \text { transmittance. } \\ \text { bacteria, viruses } & \text { Does not inactivate }\end{array}$

Similar or higher Needs to be applied to bacteria, viruses Does not inactivate 
Table 8.2 (Continued)

\begin{tabular}{|c|c|c|c|c|}
\hline $\begin{array}{l}\text { Process and } \\
\text { operating } \\
\text { conditions }\end{array}$ & Efficiency & $\begin{array}{l}\text { Nutrient } \\
\text { content }\end{array}$ & Advantages & Disadvantages \\
\hline & & & $\begin{array}{l}\text { and some } \\
\text { protozoa. } \\
\text { No toxic } \\
\text { chemicals used } \\
\text { or produced. } \\
\text { Technology well } \\
\text { known. }\end{array}$ & $\begin{array}{l}\text { helminth eggs or all } \\
\text { protozoa. } \\
\text { Performance can be } \\
\text { reduced by particulate } \\
\text { matter and biofilm } \\
\text { formation. } \\
\text { Needs good maintenance } \\
\text { of lamps. }\end{array}$ \\
\hline
\end{tabular}

\section{Soil-aquifer treatment}

\begin{tabular}{|c|c|c|c|c|}
\hline $\begin{array}{l}\text { Infiltration- } \\
\text { percolation: } \\
\text { application } \\
\text { of primary or } \\
\text { secondary } \\
\text { effluents to } \\
\text { a sand bed } \\
\text { for infiltration } \\
\text { into local } \\
\text { groundwater }\end{array}$ & $\begin{array}{l}\text { Helminth } \\
\text { eggs and } \\
\text { protozoa: } \\
\text { high (due to } \\
\text { removal in } \\
\text { sand bed) } \\
\text { Bacteria } \\
\text { and viruses: } \\
\text { high (due } \\
\text { to die-off } \\
\text { in ground- } \\
\text { water) }\end{array}$ & Low & $\begin{array}{l}\text { No water } \\
\text { losses due to } \\
\text { evaporation. } \\
\text { Simple operation. }\end{array}$ & $\begin{array}{l}\text { Requires large land area. } \\
\text { Needs good maintenance } \\
\text { of sand bed. }\end{array}$ \\
\hline $\begin{array}{l}\text { Soil-aquifer } \\
\text { treatment: } \\
\text { pumping tertiary- } \\
\text { treated waste- } \\
\text { water into a } \\
\text { local aquifer for } \\
\text { storage until next } \\
\text { irrigation season }\end{array}$ & $\begin{array}{l}\text { High (due to } \\
\text { die-off during } \\
\text { long storage) }\end{array}$ & Low & $\begin{array}{l}\text { No water } \\
\text { losses due to } \\
\text { evaporation. }\end{array}$ & $\begin{array}{l}\text { Only to be used only for } \\
\text { effluents with low organic } \\
\text { matter and suspended } \\
\text { solids contents. } \\
\text { High cost and complexity. } \\
\text { Pump maintenance often } \\
\text { problematic. }\end{array}$ \\
\hline
\end{tabular}

Source: Alcalde et al. (2006), Asano and Levine (1998), Clancy et al. (1998), Jiménez (2003, 2005), Jiménez and Chávez (2002), Jiménez and Navarro (2009), Karimi et al. (1999), Landa et al. (1997), Lazarova et al. (2000), Mara (2004), Metcalf and Eddy, Inc. (1991, 2003), NRMMC and EPHCA (2005), Rivera et al. (1995), Rojas-Valencia et al. (2004), Rose et al. (1996), Schwartzbrod et al. (1989), Sobsey (1989), Sperling and Chernicharo (2005), Sperling et al. (2003), Strauss (1996), WHO $(2004,2006)$

\section{NOTES}

1 The opinions expressed in this chapter are those of the authors and do not necessarily reflect the views or policies of the World Health Organization.

2 It is important to note that helminth egg removal efficiency provides more information when expressed as a percentage, rather than in log units (as in WHO, 2006), due to their much lower numbers in wastewater compared to those of bacteria and viruses and the need to achieve single-digit effluent qualities. 
3 Log units are, strictly, $\log _{10}$ units, such that a $4 \log$ unit reduction (for example) $=$ 99.99 per cent removal.

\section{REFERENCES}

Alcalde, L., Folch, M., Tapias, J. C., Huertas, E., Torrens, A. and Salgot, M. (2006) 'Wastewater reclamation systems in small communities', Water Science and Technology, vol 55, no 7, pp149-54

Ali, M., Al-Sa'ed, R. and Mahmoud, N. (2007) 'Start-up phase assessment of a UASBseptic tank system for treating domestic septage', Arabian Journal for Science and Engineering, vol 32, no 1C, pp65-75

Arthur, J. P. (1983) Notes on the Design and Operation of Waste Stabilization Ponds in Warm Climates of Developing Countries, Technical Paper no 7, World Bank, Washington, $\mathrm{DC}$

Asano, T. and Levine, A. D. (1998) 'Wastewater reclamation, recycling, and reuse: An introduction', in T. Asano (ed) Wastewater Reclamation and Reuse, Technomic Publishing Company, Lancaster, PA, pp1-56

Belmont, M. A., Cantellano, E., Thompson, S., Williamson, M., Sanchez, A. and Metcalfe, C. D. (2004) 'Treatment of domestic wastewater in a pilot scale natural treatment system in Mexico', Ecological Engineering, vol 23, pp299-311

Bixio, D., de Heyder, B., Cikurel, H., Muston, M., Miska, V. et al. (2005) 'Municipal wastewater reclamation: Where do we stand? An overview of treatment technology and management practice', Water Science and Technology: Water Supply, vol 5, no 1, pp77-85

Cavalcanti, P. F. F. (2003) 'Integrated application of UASB reactor and ponds for domestic sewage treatment in tropical regions', PhD thesis, Wageningen University, Wageningen, The Netherlands

Chávez, A., Jiménez, B. and Maya, C. (2004) 'Particle size distribution as a useful tool for microbial detection', Water Science and Technology, vol 50, no 2, pp179-86

Clancy, J. L., Hargy, T. M., Marshall, M. M. and Dyksen, J. E. (1998) 'UV light inactivation of Cryptosporidium oocysts', Journal of the American Water Works Association, vol 90, no 9, pp92-102

Clemett, A. E. V. and Ensink, J. H. J. (2006) 'Farmer driven wastewater treatment: A case study from Faisalabad, Pakistan', in Proceedings of the 32nd WEDC International Conference, Colombo, Sri Lanka, WEDC, Loughborough, pp99-104, available at http://wedc.lboro.ac.uk/conferences/pdfs/32/Clemett.pdf

Curtis, T. P., Mara, D. D. and Silva, S. A. (1992) 'Influence of $\mathrm{pH}$, oxygen and humic substances on ability of sunlight to damage faecal coliforms in waste stabilization pond water', Applied and Environmental Microbiology, vol 58, no 4, pp1335-45

Drechsel, P., Keraita, B., Amoah, P., Abaidoo, R., Raschid-Sally, L. and Bahri, A. (2008) 'Reducing health risks from wastewater use in urban and peri-urban sub-Saharan Africa: Applying the 2006 WHO Guidelines', Water Science and Technology, vol 57, no 9, pp1461-6

Duqqah, M. (2002) 'Treated sewage water use in irrigated agriculture. Theoretical design of farming systems in Seil Al Zarqa and the Middle Jordan Valley in Jordan', PhD thesis, Wageningen University, Wageningen, The Netherlands 
Gambrill, M. P. (1990) 'Physicochemical treatment of tropical wastewater', PhD thesis, University of Leeds, Leeds

Grimason, A., Smith, H., Thitai, W., Smith, P., Jackson, M. and Girwood, R. (1996) 'Occurrence and removal of Cryptosporidium oocysts and Giardia cysts in Kenyan waste stabilization ponds', Water Science and Technology, vol 36, no 7, pp97-104

Icekson-Tal, N., Avraham, O., Sack, J. and Cikurel, H. (2003) 'Water reuse in Israel - The Dan region project: evaluation of the water quality and reliability of plant's operation', Water Science and Technology: Water Supply, vol 3, no 4, pp231-7

IWA Specialist Group (2000) Constructed Wetlands for Pollution Control. Processes, Performance, Design and Operation, IWA Publishing, London, pp156

Jiménez, B. (2003) 'Health risks in aquifer recharge with recycled water', in R. Aertgeerts and A. Angelakis (eds) Aquifer Recharge Using Reclaimed Water, WHO Regional Office for Europe, Copenhagen, pp54-172

Jiménez, B. (2005) 'Treatment technology and standards for agricultural wastewater reuse: A case study in Mexico', Irrigation and Drainage Journal, vol 54, pp23-33

Jiménez, B. (2007) 'Helminth ova removal from wastewater for agriculture and aquaculture reuse', Water Science and Technology, vol 55, nos 1-2, pp485-93

Jiménez, B. (2009) 'Helminth ova control in wastewater and sludge for agricultural reuse', in W. O. K. Grabow (ed) Encyclopaedia of Biological, Physiological and Health Sciences, Water and Health, vol 2, UNESCO/EOLSS Publishers Co Ltd, Oxford, pp429-49

Jiménez, B., Barrios, J., Mendez J. and Diaz, J. (2004) 'Sustainable management of sludge in developing countries', Water Science and Technology, vol 49, no 10, pp251-8

Jiménez, B. and Chávez, A. (2002) 'Low-cost technology for reliable use of Mexico City's wastewater for agricultural irrigation', Technology, vol 9, nos 1-2, pp95-108

Jiménez, B. and Chávez Mejia, A. (1997) 'Treatment of Mexico City wastewater for irrigation purposes', Environmental Technology, vol 18, pp721-30

Jiménez, B., Maya, C. and Salgado, G. (2001) 'The elimination of helminth ova, faecal coliforms, Salmonella and protozoan cysts by various physicochemical processes in wastewater and sludge', Water Science and Technology, vol 43, no 12, pp179-82

Jiménez, B. and Navarro, I. (2009) 'Methodology to set regulations for safe reuse of wastewater and sludge for agriculture in developing countries based on a scientific approach and following the new WHO Guidelines', in A. Dividewi (ed) Handbook of Research on IT Management and Clinical Data Administration in Healthcare, ISI Global, New York, pp690-709

Juanicó, M. and Dor, I. (1999) Hypertrophic Reservoirs for Wastewater Storage and Reuse: Ecology, Performance, and Engineering Design, Springer Verlag, Heidelberg

Juanicó, M. and Milstein, A. (2004) 'Semi-intensive treatment plants for wastewater reuse in irrigation', Water Science and Technology, vol 50, no 2, pp55-60

Karimi, A. A., Vickers, J. C. and Harasick, R. F. (1999) 'Microfiltration goes to Hollywood: The Los Angeles experience', Journal of the American Water Works Association, vol 91, no 6, pp90-103

Landa, H., Capella, A. and Jiménez, B. (1997) 'Particle size distribution in an effluent from an advanced primary treatment and its removal during filtration', Water Science and Technology, vol 36, no 4, pp59-165

Lazarova, V., Savoye, P., MacGovern, L., Shields, P., Tchobanoglous, G., Sakaji, R. and Yates, M. (2000) 'Wastewater disinfection by UV: Evaluation of the MS2 phages as a biodosimeter for plant design', in Proceedings of the Water Reuse Association Symposium 
2000, Napa, CA, 12-15 September, Water Reuse Association, Alexandria, VA (CD$\mathrm{ROM})$

Lier, J. B. van, Zeeman, G. and Huibers, F. (2002) 'Anaerobic (pre-)treatment for the decentralized reclamation of domestic wastewater, stimulating agricultural reuse', in Proceedings of the Latin American Workshop and Symposium 'Anaerobic Digestion 7', Mérida, Yucatán, 22-25 October, www.cepis.ops-oms.org/bvsacd/unam7/anaerobic. pdf

Mara, D. (2004) Domestic Wastewater Treatment in Developing Countries, Earthscan, London

Mara, D. D., Pearson, H. W., Oragui, J. I., Cawley, L. R., de Oliveira, R. and Silva, S. A. (1997) 'Wastewater storage and treatment reservoirs in Northeast Brazil', TPHE Research Monograph no 12, School of Civil Engineering, University of Leeds, Leeds

Mara, D. D. and Silva, S. A. (1986) 'Removal of intestinal nematode eggs in tropical waste stabilization ponds', Journal of Tropical Medicine and Hygiene, vol 89, pp71-4

Metcalf and Eddy, Inc. (1991) Wastewater Engineering: Treatment, Disposal and Reuse, 3rd ed., McGraw-Hill, New York

Metcalf and Eddy, Inc. (2003) Wastewater Engineering: Treatment, Disposal and Reuse, 4th ed., McGraw-Hill, New York

Nelson, K., Jiménez-Cisneros, B., Tchobanoglous, G. and Darby, J. (2004) 'Sludge accumulation, characteristics, and pathogen inactivation in four primary waste stabilization ponds in central Mexico', Water Research, vol 38, no 1, pp111-27

NRMMC and EPHCA (2005) National Guidelines for Water Recycling: Managing Health and Environmental Risks, National Resource Management Ministerial Council and Environment Protection and Heritage Council of Australia, Canberra

Oragui, J. L., Curtis, T. P., Silva, S. A. and Mara, D. D. (1987) 'Removal of excreted bacteria and viruses in deep waste stabilization ponds in northeast Brazil', Water Science and Technology, vol 19, pp569-73

Peña, M. R., Rodrigues, J., Mara, D. D. and Spulveda, M. (2000) 'UASBs or anaerobic ponds in warm climates? A preliminary answer from Colombia', Water Science and Technology, vol 42, nos 10-11, pp59-65

Peña Varón, M. R. (2002) 'Advanced primary treatment of domestic wastewater in tropical countries: Development of high-rate anaerobic ponds', $\mathrm{PhD}$ thesis, University of Leeds, Leeds

Rivera, F., Warren, A., Ramirez, E., Decamp, O. and Bonilla, P. (1995) 'Removal of pathogens from wastewaters by the root zone method (RZM)', Water Science and Technology, vol 32, no 3, p211-18

Rojas-Valencia, M. N., Orta-de-Velásquez, M. T., Vaca-Mier, M. and Franco, V. (2004) 'Ozonation byproducts issued from the destruction of micro-organisms present in wastewaters treated for reuse', Water Science and Technology, vol 50, no 2, pp187-93

Rose, J. B., Dickson, L. J., Farrah, S. R. and Carnahan, R. P. (1996) 'Removal of pathogenic and indicator micro-organisms by a full-scale water reclamation facility', Water Research, vol 30, no 11, pp2785-97

Russell, R. C. (1999) 'Constructed wetlands and mosquitoes: Health hazards and management options - An Australian perspective', Ecological Engineering, vol 12, pp107-124

Salgot, M., Brissaud, F. and Campos, C. (1996) 'Disinfection of secondary effluents by infiltration-percolation', Water Science and Technology, vol 33, nos 10-11, pp271-6 
Schäfer, L., Lundström, J. O., Pfeffer, M., Lundkvist, E. and Landin, J. (2004) 'Biological diversity versus risk for mosquito nuisance and disease transmission in constructed wetlands in southern Sweden', Medical and Veterinary Entomology, vol 18, no 3, pp256-61

Schwartzbrod, J., Stien, J. L., Bouhoum, K. and Baleux, B. (1989) 'Impact of wastewater treatment on helminth eggs', Water Science and Technology, vol 21, no 3, pp295-7

Shuval, H., Adin, A., Fattal, B., Rawutz, E. and Yekutiel, P. (1986) Wastewater Irrigation in Developing Countries: Health Effects and Technical Solutions, World Bank Technical Paper no 51, World Bank, Washington, DC

Sobsey, M. (1989) 'Inactivation of health-related micro-organisms in water by disinfection processes', Water Science and Technology, vol 21, no 3, pp179-95

Sperling, M. von, Bastos, R. K. X. and Kato, M. T. (2004) 'Removal of E. coli and helminth eggs in UASB-polishing pond systems', paper presented at the 6th International Water Association Specialist Conference on Waste Stabilization Ponds, Avignon, France, 27 September-1 October

Sperling, M. von and Chernicharo, C. A. L. (2005) Biological Wastewater Treatment in Warm Climate Regions, IWA Publishing, London

Sperling, M. von, Chernicharo, C., Soares, A. and Zerbini, A. M. (2002) 'Coliform and helminth egg removal in a combined UASB reactor-baffled pond system in Brazil: Performance evaluation and mathematical modelling, Water Science and Technology, vol 5, no 10, pp237-42

Sperling, M. von, Chernicharo, C., Soares, A. and Zerbini, A. M. (2003) 'Evaluation and modeling of helminth egg removal in baffled and unbaffled ponds treating effluent', Water Science and Technology, vol 48, no 2, pp113-20

Stephenson, T., Judd, S., Jefferson, B. and Brindley, K. (2000) Membrane Bioreactors for Wastewater Treatment, IWA Publishing, London

Strauss, M. (1996) Health (Pathogen) Considerations Regarding the Use of Human Waste in Aquaculture, EAWAG, Dübendorf, Switzerland, www.eawag.ch/organization/ abteilungen/sandec/publikationen/publications_wra/downloads_wra/human_waste_ use_health_pathogen_risks_in_aquaculture.pdf

WEF (1996) Wastewater Disinfection, Manual of Practice No. FD-10, Water Environment Federation, Alexandria, VA

WHO (2004) Guidelines for Drinking Water Quality, 3rd ed., World Health Organization, Geneva

WHO (2006) Guidelines for the Safe Use of Wastewater, Excreta and Greywater, Volume 2: Wastewater Use in Agriculture, World Health Organization, Geneva 